\title{
Cytokine gene expression in the lungs of BALB/c mice during primary and secondary intranasal infection with Mycoplasma pneumoniae
}

\author{
Klaus Pietsch, ${ }^{1}$ Stefan Ehlers ${ }^{2}$ and Enno Jacobs ${ }^{1}$ \\ Author for correspondence: Enno Jacobs. Tel: +49761203 6529. Fax: +497612036562.
}

\begin{abstract}
1 Abteilung Mikrobiologie und Hygiene, Institut für Medizinische

Mikrobiologie und Hygiene, Klinikum der Universität Freiburg, Hermann-Herder-Str. 11, D-79104 Freiburg, Germany

2 Institut für Medizinische Mikrobiologie und Infektionsimmunologie, Freie Universität Berlin, Hindenburgdamm 27, D12203 Berlin, Germany
\end{abstract}

\begin{abstract}
Cytokine gene expression was determined in vivo in the lungs and spleens of Mycoplasma pneumoniae-infected BALB/c mice by means of qualitative and semiquantitative PCR-mediated mRNA amplification. During the acute phase of both primary and secondary infections, cytokines commonly associated with innate resistance, TNF $\alpha$, IFN $\gamma$, IL-1 $\beta$ and IL-6, were expressed. In contrast, early expression of the genes for IL-2 and IL-2 receptor was detected only during reinfection. Expression was greater in the lungs than in the spleen, attesting to the rapid accumulation of lymphocytes at the infected site. Interestingly, IL-2 mRNA expression declined rapidly and was no longer detectable after $24 \mathrm{~h}$, whereas IL-10 mRNA levels rose sharply during the same period. During reinfection, mRNAs for TNF $\alpha$ and IL-6 were 10-fold and for IFN $\gamma$ about 50-fold higher than during primary challenge. The results suggest that the pathogenesis of $M$. pneumoniae diseases may be associated with elevated expression of proinflammatory cytokines.
\end{abstract}

Keywords: Mycoplasma pneumoniae, pathogenicity, cytokines, mRNA, gene expression

\section{INTRODUCTION}

Mycoplasma pneumoniae is a well-established human pathogen causing respiratory diseases and an atypical pneumonia. The host $-M$. pneumoniae interaction is characterized by : (i) a prolonged incubation period of between $10 \mathrm{~d}$ and several weeks; (ii) slowly progressing clinical signs of fever and a nonproductive, so-called dry cough; (iii) a slowly increasing specific antibody response with high antibody titres first seen in the late acute and reconvalescent phase (Kenny et al., 1990); and (iv) in contrast to other bacterial diseases of the respiratory tract, an extension of the reconvalescence phase for a few weeks up to several months (Jacobs, 1991). Patients do not develop protective antibodies after a first natural $M$. pneumoniae infection (Razin \& Jacobs, 1992). Moreover, reinfections with $M$. pneumoniae tend to chronicity and result in more severe clinical signs (Barile, 1984). Pathological immune reactions, i.e. exacerbation of the cellular response with lympho-histiocyte infiltrations of lung tissues, induction of autoantibodies and a loss of delayed-

Abbreviation: GM-CSF, granulocyte-macrophage colony stimulating factor. type hypersensitivity reaction to tuberculin, are adverse events in the course of prolonged disease (Jacobs et al., 1988; Jacobs et al., 1990; Lind et al., 1992; Rollins et al., 1986; Tsunekawa et al., 1987).

The regulation of protective and inflammatory phenomena at the site of infection is thought to involve the release of soluble mediators that attract, focus and activate other cells of myelomonocytic origin. To promote understanding of the interaction of $M$. pneumoniae with the host's immune response during the acute phase of primary and secondary intranasal challenge, this study focused on the role of in vivo cytokine gene expression in the lungs early after infection.

Data on cytokine production in $M$. pneumoniae infection are scarce. Most investigators have determined cytokine levels in human peripheral blood mononuclear cells stimulated, in vitro, by $M$. pneumoniae antigen (Kita et al., 1992; Nakayama et al., 1992). These results may, however, not adequately reflect the local immune response in infected tissues. We have therefore adapted the exquisitely sensitive technique of PCR-mediated mRNA amplification (Ehlers \& Smith, 1991) to determine, for the first time in in vivo experiments, cytokine mRNA levels in the lungs during the acute phase of $M$. pneumoniae infections in 
an established animal model (Pietsch \& Jacobs, 1993; Street \& Mosmann, 1991).

\section{METHODS}

Bacterial strain and animals. M. pneumoniae (strain FH) was grown in Hayflick modified Eagle's medium in Roux bottles for $48 \mathrm{~h}$ at $37^{\circ} \mathrm{C}$ (Hayflick, 1965). Fresh, glass-adherent mycoplasmas were harvested with a cell-scraper, washed in phosphate-buffered saline (PBS; $0.14 \mathrm{M} \mathrm{NaCl}, 0.01 \mathrm{M}$ sodium phosphate, $\mathrm{pH} 7 \cdot 2$ ), and re-suspended in PBS to $\mathrm{OD}_{660}() \cdot 15$ (approx. $10^{8}$ c.f.u. $\mathrm{ml}^{-1}$ ). Mycoplasma-free BALB/c mice (3-4 months old; Center for Laboratory Animals, Hannover, Germany) were infected intranasally under anaesthesia as described recently (Pietsch \& Jacobs, 1992). The inoculum for primary infection was (per mouse) $2 \times 10^{7}$ c.f.u. and for reinfections $5 \times 10^{7}$ c.f.u. in $0.05 \mathrm{ml}$ PBS. Reinfection was carried out $20 \mathrm{~d}$ after primary infection.

RNA isolation and cDNA synthesis. Three control (uninfected), primarily infected and reinfected mice were killed at various times from $30 \mathrm{~min}$ to $5 \mathrm{~d}$ after intranasal inoculation with PBS (control) or $M$. pneumoniae cells. Lungs and spleens were removed, homogenized immediately in $10 \mathrm{ml}$ lysis buffer $(4 \mathrm{M}$ guanidine isothiocyanate (Merck), containing $25 \mathrm{mM}$ sodium citrate (pH 7), 0.5\% N-lauroylsarcosine (Sigma) and $100 \mathrm{mM}$ 2-mercaptoethanol (Sigma), and frozen at $-70^{\circ} \mathrm{C}$. Total RNA was extracted with phenol/chloroform as described by Chomczynski \& Sacchi (1987). RNA precipitates were pelleted at $4{ }^{\circ} \mathrm{C}$ with 2 -propanol, washed once with $75 \%$ ethanol in diethylpyrocarbonate-treated distilled water and repelleted at $12000 \mathrm{~g}$ for $15 \mathrm{~min}$. Vacuum-dried pellets were resuspended in $10 \mu \mathrm{l}$ diethylpyrocarbonate-treated distilled water containing $2 \mu \mathrm{g}$ oligo-dT (12- to 18-mer; United States Biochemical) and incubated at $65^{\circ} \mathrm{C}$ for $10 \mathrm{~min}$. After cooling on ice for $5 \mathrm{~min}$, the mixture was incubated, in a total volume of $20 \mu \mathrm{l}$, with reverse transcriptase buffer (double-strength buffer: $100 \mathrm{mM}$ Tris/ $\mathrm{HCl}, \mathrm{pH} \mathrm{8.3;} 150 \mathrm{mM} \mathrm{KCl}, 6 \mathrm{mM} \mathrm{MgCl}, 20 \mathrm{mM}$ dithiothreitol), $200 \mathrm{U}$ of Moloney murine leukemia virus superscript reverse transcriptase (BRL-GIBCO, Life Technologies), $1 \mathrm{mM}$ deoxynucleotides, $100 \mu \mathrm{g}$ acetylated bovine serum albumin (BSA) $\mathrm{ml}^{-1}$ and $25 \mathrm{U}$ of ribonuclease inhibitor (RNasin; Promega) for $90 \mathrm{~min}$ at $37^{\circ} \mathrm{C}$. Tubes were then heated to $95^{\circ} \mathrm{C}$ for 5 to $10 \mathrm{~min}$, and $180 \mu \mathrm{l}$ of distilled water was added to each $20 \mu \mathrm{l}$ reaction mixture. Samples were stored at $4{ }^{\circ} \mathrm{C}$. Reverse transcriptase reactions of samples from primary and secondary infections and controls were always performed simultaneously.

PCR conditions. Cytokine-specific primer pairs (sense and antisense, respectively) were used as follows (sizes of amplified fragments are given in parentheses). $\beta_{2}$-Microglobulin: (sense) 5' GGCTCGCTCGGTGACCCTAGTCTTT 3' and (antisense) 5' TCTGCAGGCGTATGTATCAGTCTCA 3' (300 bp); IL-1 $\beta: 5^{\prime}$ 'TCATGGGATGATGATGATAACCTGCT $3^{\prime}$ and 5' CCCATACTTTAGGAAGACACGGATT $3^{\prime}$ (502 bp); IL-2: 5' ATGTACAGCATGCAGCTCGCATCC'TGTGTCA $3^{\prime}$ and $5^{\prime}$ AGTCAAATCCAGAACATGCCGCAGAGGTCCA 3' (320 bp); IL-3: 5' ATGGTTCTTGCCAGCTCTACCACCA $3^{\prime}$ and 5' GATAAGACATTTGATGGCATAAAGGA 3' (592 bp); IL-4: 5' ACAAAAATCACTTGAGAGAGATCA'T $3^{\prime}$ and $5^{\prime}$ AGTAATCCAT'TTGCATGATGCTCT' 3' (351 bp); IL-6: 5' CTGGTGACAACCACGG-
CCTTCCCTA $3^{\prime}$ and 5' ATGCT'TAGGCATAACGCACTAGGTT 3' (600 bp); IL-10: 5' ACCTGGTAGAAGTGATGCCCCAGGCA $3^{\prime}$ and 5' CTATGCAGTTGATGAAGATGTCAAA 3' (237 bp); GM-CSF (granulocyte-macrophage colony stimulating factor): 5' ATGTGGCTGCAGAATTTACTTTTCC'T $3^{\prime}$ and 5' TGGGCTTCCTCAT'TTTTGGCCTGGT 3' (435 bp); TNF $\alpha$ : 5' AGCCCACGTCG'TAGCAAACCACCAA $3^{\prime}$ and 5' ACACCCATTCCCTTCACAGAGCAAT 3' (446 bp); IFN $\gamma$ : 5' GAAAGCCTAGAAAGTCTGAATAACT $3^{\prime}$ and $5^{\prime}$ A TCAGCAGCGACTCCT'T TTCCGCTT 3' (388 bp); IL-2R p55 subunit: 5' TCCTGGAGCAGCAACTGCCAGTGCACCAGCA $3^{\prime}$ and 5' CTTATACTCCATTGTGAGCACAAATGTCT 3' (501 bp). The primers were designed and assessed for specificity by a computer-assisted search of updated versions of GenBank. The $5^{\prime}$ - and $3^{\prime}$-primers are complementary to sequences in different exons or spanned exon-exon junctions and are therefore $\mathrm{mRNA} / \mathrm{cDNA}$ specific. The 5 -primers were designed to all recognized sequences approximately $1000 \mathrm{bp}$ upstream of the poly( $\mathrm{T})$ tract of the cDNA to minimize potential errors caused by differential reverse transcription (Ehlers et al., 1992). All primers used were purchased from Tib Molbiol (Berlin, Germany).

Five microlitres of cDNA was amplified in $0.5 \mathrm{ml}$ GeneAmp reaction tubes (Perkin-Elmer) in the presence of $5 \mu \mathrm{l} 200 \mathrm{nM} \mathrm{5}$ and 3 '-primers and $15 \mu \mathrm{l} \mathrm{PCR} \mathrm{mix} \mathrm{containing} 200 \mu \mathrm{M}$ deoxynucleotides, $0.5 \mathrm{U}$ of Taq polymerase (Perkin-Elmer), and PCR buffer $(2.5 \mathrm{mM} \mathrm{MgCl}, 50 \mathrm{mM} \mathrm{KCl}, 10 \mathrm{mM}$ Tris/ $\mathrm{HCl}$, and $0.001 \%$ gelatin) in a final volume of $25 \mu \mathrm{l}$. The reaction mixture was overlaid with a drop of light mineral oil (Sigma), and PCR was performed in a DNA Thermocycler (Perkin-Elmer) for 30 cycles: $30 \mathrm{~s}$ denaturation at $94^{\circ} \mathrm{C}, 45 \mathrm{~s}$ annealing at $60^{\circ} \mathrm{C}$, and $1 \mathrm{~min}$ extension at $72^{\circ} \mathrm{C}$. In all experiments, control PCRs without cDNA were performed to test for contamination. The reaction product was visualized by electrophoresis using $20 \mu \mathrm{l}$ reaction mixture at $120 \mathrm{~V}$ for $60 \mathrm{~min}$ in $2 \%$ agarose in half strength tris/boric acid/EDTA buffer (single-strength buffer: $0.089 \mathrm{M}$ Tris $/ \mathrm{HCl}, 0.088 \mathrm{M}$ boric acid, $0.002 \mathrm{M}$ EDTA) containing $0.5 \mu \mathrm{g}$ ethidium bromide $\mathrm{ml}^{-1}$. One microgram of HincII-digested $\phi \mathrm{X} 174$ DNA was run in parallel as molecular size markers, providing bands at $1057,770,612,495,392,345$, $341,335,297,291,162$ and $79 \mathrm{bp}$. The specificity of the amplified target sequences was validated by their predicted size. PCR-assisted mRNA amplification was repeated at least twice for at least two separately prepared cDNA samples. Data shown are representative of at least three different experiments.

Semiquantitative PCR. To compare separate samples quantitatively, PCR was performed on target CDNA serially diluted 10 -fold using primers specific for $\beta$-actin, IFN $\gamma$, IL- 6 and TNF $\alpha$ in the presence of a constant amount of competitor control fragment consisting of 5 '- and $3^{\prime}$-primer sequences in tandem array (Platzer et al., 1992). Primer sequences used for competitive PCR were used as described by Murray et al. (1990). The $5^{\prime}$ - and $3^{\prime}$-sequences were selected in such a way that the sizes of the specifically amplified control fragment and cDNA differed from each other and could be distinguished by agarose gel electrophoresis. During co-amplification, both target and control DNA compete for the primers and the amount of PCR products are proportional to the initial amount of cDNA. For determination of mRNA levels, the control fragment was added at dilutions ranging from $10^{-6}$ to $10^{-8}$. In the first step, competitive PCR was performed on all samples to establish that the cDNA contained equivalent concentrations of $\beta$-actin cDNA before determining cytokine mRNA levels (O'Garra \& Vieira, 1992). If samples contained similar amounts of amplifiable cDNA compared to control DNA equally dense bands were seen in the agarose gel. 


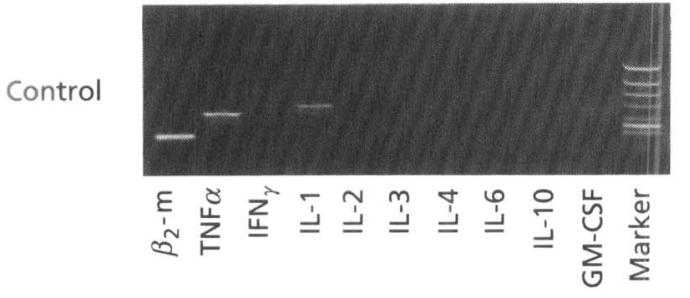

Primary infection
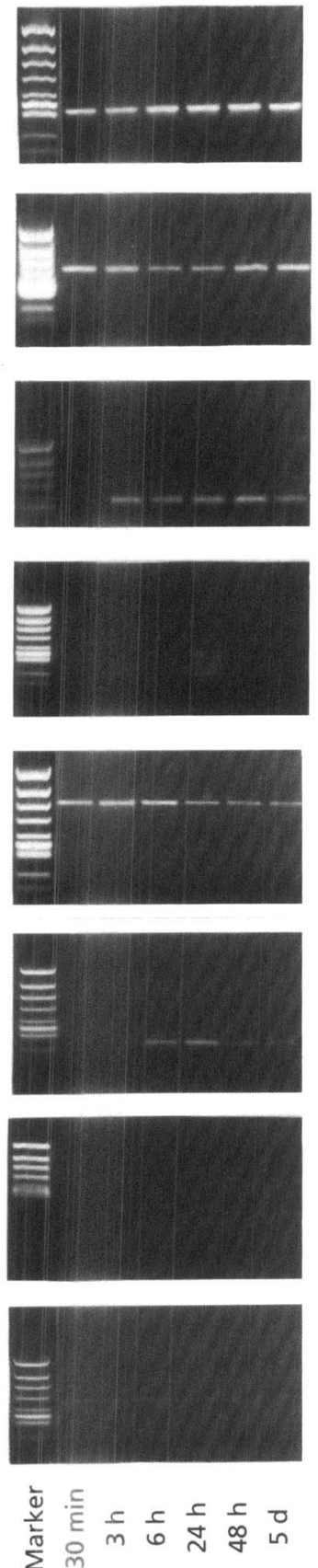

GM-CSF (435 bp)

Secondary infection

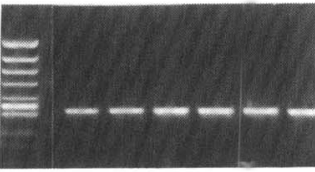

TNF $\alpha$ (446 bp)

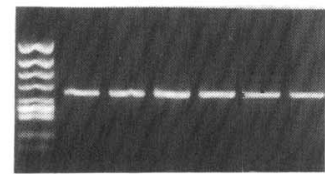

IFN (388 bp)

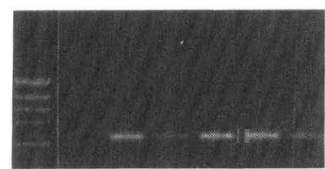

IL-2 (320 bp)

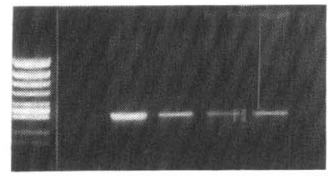

IL-6 (600 bp)

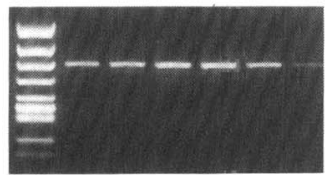

IL- 10 (237 bp)

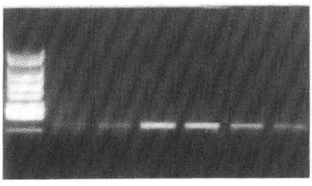

IL-2R (501 bp)
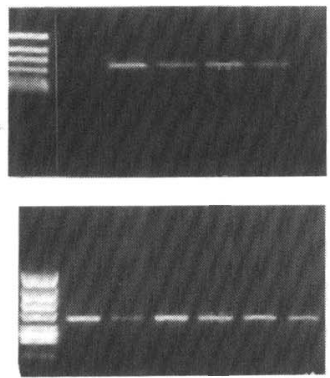

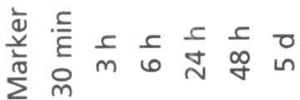

Fig. 1. $P C R$-amplified cytokine mRNA from the lungs of control (uninfected), primarily and secondarily infected BALB/C mice. Lungs were removed $30 \mathrm{~min}, 3 \mathrm{~h}$ and up to $5 \mathrm{~d}$ after intranasal infection with $M$. pneumoniae or PBS (control mice). $\beta_{2}-\mathrm{m}, \beta_{2^{-}}$ microglobulin; marker, Hincll-digested $\phi$ X174 DNA.

\section{RESULTS}

\section{Kinetic analysis of cytokine gene expression during primary and secondary infection with $M$. pneumoniae}

To compare cytokine mRNA expression during primary and secondary infection with $M$. pneumoniae, lungs of $\mathrm{BALB} / \mathrm{c}$ mice were removed at $30 \mathrm{~min}, 3 \mathrm{~h}, 6 \mathrm{~h}, 24 \mathrm{~h}$, $48 \mathrm{~h}$ and $5 \mathrm{~d}$ following intranasal infection. PCR amplification showed the presence of TNF $\alpha$ and IL- $1 \beta$ mRNA $30 \mathrm{~min}$ after primary and secondary infections and in control mice, whereas IFN $\gamma$, IL-6 and GM-CSF (which gave only a faint band) were detected in infected mice only (Fig. 1). The band corresponding to IL-10 mRNA was prominent after $6 \mathrm{~h}$ in secondary infections whereas at this time during primary infections it was only weakly expressed. T-cell-specific cytokine mRNA expression, for IL-2 and the IL-2 receptor (IL-2R p55 subunit) was detected $3 \mathrm{~h}$ after reinfection but had ceased by $48 \mathrm{~h}$ (Fig. 1). T-cell-specific cytokine mRNA expression could not be detected in lungs during the first $5 \mathrm{~d}$ of primary infections. In both primary and secondary infection, we were unable to detect IL-3 and IL- 4 mRNA expression.

\section{Semiquantitative assessment of cytokine mRNA}

To compare the amount of cytokine mRNA in lung tissues during primary and secondary infections, a competitive PCR was used. The cDNAs were serially diluted (10-fold steps) before PCR analysis in the presence of primers and a constant amount of competitor control fragment consisting of $5^{\prime}$ - and $3^{\prime}$-primer sequences in a tandem array.

The results enabled semiquantitative comparison of cytokine mRNA expression. After $6 \mathrm{~h}$ of primary and secondary infection, there was no difference in the level of expression of $\beta$-actin (internal control). However, in lungs of reinfected mice after both $3 \mathrm{~h}$ (data not shown) and $6 \mathrm{~h}$, expression of TNF $\alpha$ and IL- $6 \mathrm{mRNA}$ was approximately 10-fold greater, and IFN $\gamma$ about 50-fold (between 10-fold and 100 -fold) greater, than in primarily infected mice (Fig. 2 ). In primarily infected lungs, TNF $\alpha$ and IL- $1 \beta$ mRNA were elevated about 10 -fold in comparison to the noninfected controls (data not shown).

\section{Comparison of cytokine gene expression in lung and spleen}

To define differences in local and systemic cytokine expression, lungs and spleens were removed from secondarily infected mice. TNF $\alpha$, IFN $\gamma$ and IL- $1 \beta$ mRNA were detected in both lungs and spleens $3 \mathrm{~h}$ and $6 \mathrm{~h}$ after infection. However, IL- 2 and IL- 6 mRNAs, which were present at relatively high concentrations in lung tissues, were transcribed to only a minor extent in spleens (Fig. 3; $3 \mathrm{~h}$ results not shown). GM-CSF mRNA was only detected in lungs.

\section{DISCUSSION}

The fastidious and slow-growing $M$. pneumoniae cells 
Primary infection
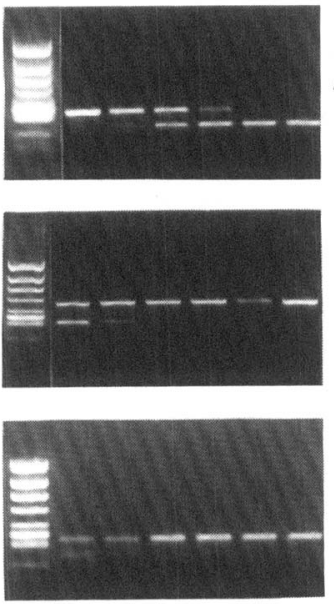

CF (315 bp) IFN $_{\gamma}(243 \mathrm{bp})$

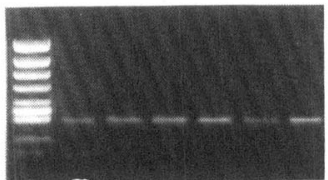
IL-6 (154 bp)

CF (438 bp)
Secondary infection

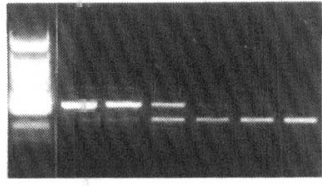
$\operatorname{TNF} \alpha(307 \mathrm{bp})$
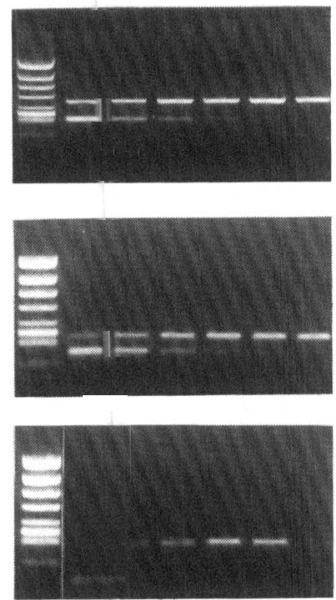

Fig. 2. Competitive semiquantitative PCR amplification of cytokine mRNA from lungs of primarily and secondarily infected BALB/C mice ( $6 \mathrm{~h}$ after intranasal infection). To compare separate samples quantitatively, PCR was performed on target CDNA serially diluted 10 -fold using primers specific for $\beta$ actin, TNF $\alpha$, IFN $\gamma$ and IL- 6 in the presence of a constant amount of competitor control DNA consisting of $5^{\prime}$ - and 3'-primer sequences in tandem array. CF, control competitor DNA fragment.

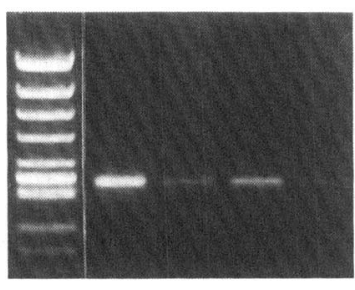

IL-2

(320 bp)

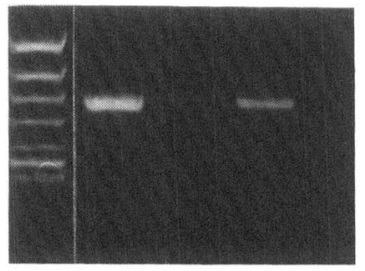

IL-6

(600 bp)

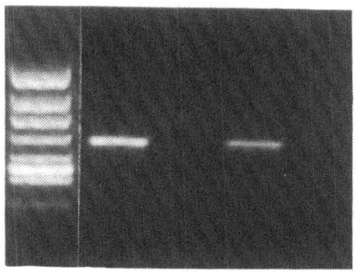

GM-CSF

(435 bp)

\begin{tabular}{|c|c|c|}
\hline ع & ع & ع \\
\hline$m$ & $m$ & 6 \\
\hline تـ & vi & - \\
\hline
\end{tabular}

Fig. 3. $P C R$-amplified cytokine $m R N A$ from the lungs and spleens of secondarily infected BALB/C mice ( $6 \mathrm{~h}$ after infection). L, lung; S, spleen.

colonize host respiratory epithelium cells. In in vitro experiments, it has been shown that only specifically opsonized $M$. pneumoniae cells are phagocytosed by alveolar macrophages (Kist et al., 1982), indicating that $M$. pneumoniae may escape non-specific host response mechanisms. We used a high infecting inoculum to mimic the 'post-propagation' phase of $M$. pneumoniae infection in humans. It has been documented that especially during secondary infections with $M$. pneumoniae an exacerbation of the cellular response may aggravate the disease. Histological examination of affected lungs has revealed peribronchial and perivascular histiolymphocytic infiltrations (Jacobs et al., 1988). It was therefore of interest to compare the acute phase of both primary and secondary infection in order to study the involvement of cytokines in the acute inflammatory process.

We have conducted a kinetic and quantitative analysis of cytokine mRNA expression in the lungs of control and immune mice infected with $M$. pneumoniae. Five important findings emerge from these studies. (i) During primary infection, transcription of cytokine genes for $T N F \alpha$, IFN $\gamma$, IL- $1 \beta$ and IL- 6 was observed. This result is in keeping with the interpretation that these cytokines, thought to be involved in innate resistance to bacterial infection, are non-specifically produced early during inflammation (Ehlers et al., 1992; Hirano et al., 1990; Pirmez et al., 1993). (ii) During secondary infection, the expression of granulocyte-macrophage colony stimulating factor, acting in the bone marrow as a growth and differentiation factor, was increased only in the lungs of infected animals. (iii) The expression of TNF $\alpha$ and IL-1 $\beta$ mRNA was elevated 10 -fold in primarily infected mice when compared to control mice. During reinfection the expression of proinflammatory cytokines like $\mathrm{TNF} \alpha$ and IL- 6 were 10 -fold and for IFN $\gamma$ about 50 -fold higher as early as $6 \mathrm{~h}$ after challenge when compared to primary infection. (iv) During secondary infection, $m R N A$ for IL2 , detected as early as $3 \mathrm{~h}$ after challenge, was present at higher concentrations in the lungs of infected animals 
than in the spleens, providing direct evidence that lymphocytes infiltrate the site of infection (Pabst, 1992). (v) IL-2 mRNA expression was transient, peaking at 3-6 $\mathrm{h}$ post reinfection, and becoming undetectable by $48 \mathrm{~h}$, while, concomitantly, IL-10 mRNA levels rose sharply.

The cytokine pattern characteristic of primary infection [see (i) above] has also been found in ELISA and bioassays in in vitro experiments with human peripheral blood mononuclear cells after stimulation with $M$. pneumoniae cells (Kita et al., 1992). In contrast, secondary $M$. pneumoniae infection is characterized by a distinct cytokine pattern: the presence of IL-2 and IL-2R mRNAs attests to the accumulation and activation of T-cells in the infected tissues as early as $3 \mathrm{~h}$ after reinfection. In addition, TNF $\alpha$ and IFN $y$ mRNA levels are significantly increased. At present, the cellular source for this enhanced expression remains unknown, but IL-2 (from T cells) has been shown to increase production of TNF $\alpha$ and IFN $\gamma$ in other cells of myelomonocytic origin (Cuturi et al., 1989).

In man, the acute phase of $M$. pneumoniae infection is characterized by a non-specific polymorphonuclear leucocyte-rich exudate in the bronchiolar lumen (Rollins et al., 1986). This recruitment of myelomonocytic cells correlates well with the characteristic cytokine pattern documented in this study of the early stages of infection in mice. Subsequent to these early events, there is a lymphoplasmocytic infiltration of the bronchiolar and perivascular walls (Jacobs $e$ t al., 1988; McGee \& TaylorRobinson, 1981; Pietsch \& Jacobs, 1993). In hamsters, the cuff formation around the bronchial tract and the small vessels shows a maximum at about $14 \mathrm{~d}$ after challenge (Barile et al., 1988; Cimolai et al., 1992). The majority of the lymphocytes that cuff the bronchial tree are T-cells, and thymectomy has been shown to prevent the accumulation of peribronchial lymphocytic infiltrations (McGee \& Taylor-Robinson, 1981). It is possible that these lymphocytic infiltrations, reminiscent of a delayed-type hypersensitivity reaction, are due to prolonged TNF $\alpha$ and/or IFN $\gamma$ stimulation of the vasculature, as has been demonstrated in other disease models of chronic inflammation (Kindler et al., 1989; Mielke et al., 1992). Identification of the cellular and molecular mediators of this aspect of disease awaits the results of ex vivo analyses of the later stages of disease.

It is important to emphasize that our present studies are strictly confined to the acute phase of primary and secondary infections with $M$. pneumoniae and do not directly address the involvement of cytokines in the immunopathology of prolonged and chronic disease. Nevertheless, there is a clear indication that the immune response during secondary infection is accelerated and distinctly more pronounced in terms of the expression of proinflammatory cytokines. The finding that IL-2 mRNA expression was transient (up to $48 \mathrm{~h}$ ) is most striking, particularly since the disappearance of IL-2 mRNA is coincident with the appearance of IL-10 mRNA during secondary infection. Bearing in mind the concept of crossregulatory networks of cytokine-secreting cells, it is tempting to speculate that IL-10 serves to turn off the specific T-cell response (Fiorentino et al., 1991). The cellular source of the IL-10 mRNA detected in these studies is at present unclear, and cellular depletion experiments aimed at defining its origin are in progress.

Future studies will also be directed at (i) identifying the cellular components responsible for expression of the other cytokines produced in response to $M$. pneumoniae infection and detected in this study; (ii) correlating cytokine patterns with histomorphological findings in order to define the relative contribution of distinct cytokines in inflammatory and protective events during $M$. pneumoniae infection. In this regard, it will be of particular interest to scrutinize more closely the later phase of infection during which dense lymphocytic infiltrations develop in the peribronchial space. Correlating cytokine patterns with immunopathological findings is a first step in our attempt to develop immunomodulatory strategies aimed at reducing disease-promoting mechanisms whilst leaving protective mechanisms unimpaired.

\section{ACKNOWLEDGEMENTS}

We thank Stefanie Schaps for her excellent technical assistance. This work was supported by a grant from the Deutsche Forschungsgemeinschaft (Ja 399/7-1).

\section{REFERENCES}

Barile, M. F. (1984). Immunization against Mycoplasma pneumoniae disease: a review. Isr J Med $S_{c i}$ 20, 912-915.

Barile, M. F., Chandler, D. K. F., Yoshida, H., Grabowski, M. W., Harasawa, R. \& Razin, S. (1988). Parameters of Mycoplasma pneumoniae infection in Syrian hamsters. Infect Immun 56, 2443-2449.

Chomczynski, P. \& Sacchi, N. (1987). Single-step method of RNA isolation by acid guanidinium thiocyanate-phenol-chloroform extraction. Anal Biochem 162, 156-159.

Cimolai, N., Taylor, G. P., Mah, D. \& Morrison, B. J. (1992). Definition and application of a histopathological scoring scheme for an animal model of acute Mycoplasma pneumoniae pulmonary infection. Microbiol Immunol 36, 465-478.

Cuturi, M. C., Anegon, I., Sherman, F., Loudon, R., Clark, S. C., Perussia, B. \& Trinchieri, G. (1989). Production of hematopoietic colony-stimulating factors by human natural killer cells. J Exp Med 169, 569-583.

Ehlers, S. \& Smith, K. A. (1991). Differentiation of T cell lymphokine gene expression: the in vitro acquisition of $\mathrm{T}$ cell memory. $J$ Exp Med 173, 25-36.

Ehlers, S., Mielke, M. E. A., Blankenstein, T. \& Hahn, H. (1992). Kinetic analysis of cytokine gene expression in the liver of naive and immune mice infected with Listeria monocytogenes. The immediate early phase in innate resistance and acquired immunity. J Immunol 149, 3016-3022.

Fiorentino, D. F., Zlotnik, A., Vieira, P., Mosmann, T. R., Howard, M., Moore, K. W. \& O'Garra, A. (1991). IL-10 acts on the antigenpresenting cells to inhibit cytokine production by Th1 cells. J Immunol 146, 3444-3451.

Hayflick, L. (1965). Cell cultures and mycoplasmas. Tex Rep Biol Med 23, 285-303.

Hirano, T., Akira, S., Taga, T. \& Kishimoto, T. (1990). Biological and clinical aspects of interleukin 6. Immunol Today 11, 443-449. 
Jacobs, E., Drews, M., Stuhlert, A., Büttner, C., Klein, P. J., Kist, M. \& Bredt, W. (1988). Immunological reactions of guinea pigs following intranasal Mycoplasma pneumoniae infection and immunization with the $168 \mathrm{kDa}$ adherence protein. J Gen Microbiol 134, 473-479.

Jacobs, E., Röck, R., Dalehite, L. \& Bredt, W. (1990). A B-cell T-cell linked epitope of Mycoplasma pneumoniae. Infect Immun 58, 2464 2469 .

Jacobs, E. (1991). Mycoplasma pneumoniae virulence factors and the immune response. Rev Med Microbiol 2, 83-90.

Kenny, G. E., Kaiser, G. G., Cooney, M. K. \& Foy, H. M. (1990). Diagnosis of Mycoplasma pneumoniae pneumonia: sensitivities and specificities of serology with lipid antigen and isolation of the organism on soy peptone medium for identification of infections. J Clin Microbiol 28, 2087-2093.

Kindler, V., Sappino, A. P., Grau, G. E., Piguet, P. F. \& Vassalli, P. (1989). The inducing role of tumor necrosis factor in the development of bacterial granulomas during BCG infection. Cell 56, 731-740.

Kist, M., Jacobs, E. \& Bredt, W. (1982). Release of Mycoplasma pneumoniae substances after phagocytosis by guinea pig alveclar macrophages. Infect Immun 36, 357-362.

Kita, M., Ohmoto, Y., Hirai, Y., Yamaguchi, N. \& Imanishi, J. (1992). Induction of cytokines in human peripheral blood mononuclear cells by mycoplasmas. Microbiol Immunol 5, 507-516.

Lind, K., Hoier-Madson, M., Wilk, A. \& Clyde, W. A., Jr (1992). Antibodies to the mitotic spindle apparatus in patients with Mycoplasma pneumoniae infection. Immunol \& Infect Dis 2, 249-255.

McGee, Z. A. \& Taylor-Robinson, D. (1981). Mycoplasmas in medical microbiology and infectious diseases. In Medical Microbiology and Infectious Diseases, pp. 522-528. Edited by A. I. Braude. Philadelphia: W.B. Saunders.

Mielke, M. E. A., Rosen, H., Brocke, S., Peters, C. \& Hahn, H. (1992). Protective immunity and granuloma formation are mediated by two distinct tumor necrosis factor alpha- and gamma-interferon dependent $T$ cell-phagocyte interactions in murine listeriosis: dissociation on the basis of phagocyte adhesion mechanisms. Infect Immun 60, 1875-1882.

Murray, L. J., Lee, R. \& Martens, C. (1990). In vivo cytokine gene expression in T cell subsets of the autoimmune MRL/Mp-Ipr/Ipr mouse. Eur J Immunol 20, 163-170.

Nakayama, T., Sonoda, S., Urano, T., Osano, M., Maehara, N. Sasaki, K., Hayatsu, E. \& Makino, S. (1992). Interferon production during the course of Mycoplasma pneumoniae infection. Pediatr Infect Dis J 11, 72-77.

O'Garra, A. \& Vieira, P. (1992). Polymerase chain reaction for detection of cytokine gene expression. Curr Opin Immunol 4, $211-215$.

Pabst, R. (1992). Is BALT a major component of the human lung immune system? Immunol Today 13, 119-122.

Pietsch, K. \& Jacobs, E. (1993). Characterization of the cellular response of spleen cells in BALB/c mice inoculated with Mycoplasma pneumoniae or the P1 protein. Med Microbiol Immunol 182, 77-85.

Pirmez, C., Yamamura, M., Uyemura, K., Paes-Oliveira, M. \& Conceicao-Silva, F. (1993). Cytokine patterns in the pathogenesis of human leishmaniasis. J Clin Invest 91, 1390-1395.

Platzer, C., Richter, G., Ueberla, K., Mueller, W., Bloecker, H. \& Diamantenstein, T. (1992). Analysis of cytokine mRNA levels in interleukin-4-transgenic mice by quantitative polymerase chain reaction. Eur J Immunol 22, 1179-1184.

Razin, S. \& Jacobs, E. (1992). Review article: Mycoplasma adhesion. $J$ Gen Microbiol 138, 407-422.

Rollins, S., Colby, T. \& Clayton, F. (1986). Open lung biopsy in Mycoplasma pneumoniae pneumonia. Arch Pathol Lab Med 110, 34-41.

Street, N. E. \& Mosmann, T. R. (1991). Functional diversity of $T$ lymphocytes due to secretion of different cytokine patterns. FASEB J 5, 171-177.

Tsunekawa, H., Takagi, E., Kishimoto, H. \& Shimokata, K. (1987). Depressed cellular immunity in Mycoplasma pneumoniae pneumonia Eur J Respir Dis 70, 293-299.

Received 14 December 1993; revised 23 March 1994; accepted 7 April 1994. 